\title{
BIBLIOGRAPHIC INFORMATION:
}

Ballantyne, J. (2007) Crossing barriers between teacher preparation and teaching:

Documenting praxis shock in early-career music teachers. International Journal of Music Education. 25(3), 181-191. Found online at http://ijm.sagepub.com/

Documenting praxis shock in early-career Australian music teachers: the impact of preservice teacher education ${ }^{i}$

\begin{abstract}
Early-career music teachers are well placed to comment on the effectiveness of pre-service teacher education. Their perceptions are particularly relevant in determining why music teachers are 'burning out' at an early stage of their career. This paper explores 15 early-career Australian music teachers' perceptions of their job, and their perceived preparedness for the workforce. Their stories suggest that although they feel a 'passion' towards teaching music, they see their early experiences in secondary schools as a time where they will either 'sink or swim', and where they see themselves as a 'one-manband'. Analysis suggests that praxis shock in early-career music teachers is directly related to the unique experiences of being a music teacher. The paper concludes with recommendations for pre-service courses to address issues of praxis shock in early-career music teachers.
\end{abstract}

\section{Key words}

early-career music teachers, praxis shock, pre-service preparation, professional isolation, teacher education 


\section{Introduction}

Early experiences as a teacher are crucial, and in many ways determine beginning teachers' attitudes towards teaching. The first few years in the classroom shape teachers' ongoing professional identity, classroom practice and longevity in the profession (Flores, 2001; Ghaith \& Shaaban, 1999; Gratch, 2001; Hawkey, 1996; Wideen, Mayer-Smith, \& Moon, 1998).

In many cases, the reality that beginning teachers are faced with differs from their expectations and causes them to re-evaluate their preconceived notions about teaching (Kelchtermans \& Ballet, 2002). The discrepancies between teachers’ expectations of school life and the realities of teaching often contribute to what is known as praxisschock (Mark, 1998) and is also referred to as praxis shock (Kelchtermans \& Ballet, 2002) or practice shock (Stokking, Leenders, De Jong, \& Van Tartwijk, 2003). When teachers' expectations of teaching life are 'shattered' as beginning teachers, they tend to focus on survival rather than on learning how to teach more effectively (Wideen et al., 1998) and in many cases, the school environment becomes more powerful than pre-service education in determining teacher practice (Lampert \& Ball, 1999; Stuart \& Thurlow, 2000; Su, 1992).

Teacher education plays a key role in helping teachers develop a realistic understanding of the realities of teaching life (Gratch, 2001; Kelchtermans \& Ballet, 2002). If teacher education preparation has not been effective in preparing teachers, teachers may reject the knowledge and skills that they learned at university and unthinkingly adopt the teaching culture at their school.

Although praxis shock is likely to occur across all discipline areas, it is important to explore the experiences of teachers within particular discipline areas as teachers generally tend to view themselves as discipline or age-level specialists (Martinez, 1994; Ramsey, 2000; Shulman \& Sparks, 1992). Within music teacher education, research has explored how preservice music teachers learn to be teachers (Yourn, 2000), perceived problems of beginning Ballantyne, J. (2007) Crossing barriers between teacher preparation and teaching: Documenting praxis shock in early-career2 music teachers. International Journal of Music Education. 25(3), 181-191. Found online at http://ijm.sagepub.com/ 
music teachers (DeLorenzo, 1992; Krueger, 2000; Richards \& Killen, 1993), role stress of experienced instrumental and choral music teachers (Scheib, 2003), teachers' perceptions of their induction experiences (DeLorenzo, 1992; Conway 2002), the effectiveness of preservice courses in preparing primary and instrumental teachers to teach music (Conway, 2002; Temmerman, 1997), the competencies required by beginning music teachers (Leong, 1996), and early-career classroom music teachers' perceptions of the effectiveness of their course in light of their pre-service teacher education (Ballantyne, 2006). Studies by both Leong (1996) and Kelly (1999) suggest that 'burnout' is a feature of early-career music teachers' lives in Australia, and Queensland specifically. However, no research has specifically documented the areas where this occurs. This paper fills the gap in the literature, by providing evidence of the areas where music teachers are experiencing praxis shock in Queensland, Australia, and highlighting where teacher preparation needs to address earlycareer $^{\mathrm{ii}}$ music teachers’ perceived needs.

\section{Context for the research}

This study involved early-career secondary music teachers in Queensland, Australia who had graduated from one of three pre-service education programs. All accredited teacher education programs in Queensland have to comply with the Queensland Board of Teacher Registration’s (1999) guidelines regarding philosophies, goals, structure and content of programs, teaching and learning approaches, and assessment of student work. As a result, pre-service teacher education programs at all Queensland universities are quite similar.

\section{Method}

As part of a larger study exploring the effectiveness of music teacher education programs in Queensland, fifteen early-career music teachers were interviewed regarding their experiences 
as beginning music teachers. Based on their responses to a questionnaire (the results of which are not the focus of this paper), participants were selected to represent varied teaching experiences and perceptions on the effectiveness of the course. Briefly, the interviewees comprised 11 females and 4 males, the majority of whom were either somewhat satisfied or somewhat dissatisfied with their pre-service course and three who were very satisfied with their pre-service course. They were a mixture of $1^{\text {st }}, 2^{\text {nd }}, 3^{\text {rd }}$ and $4^{\text {th }}$ year teachers from a variety of schools including both metropolitan and rural schools in private and public schooling systems. The interview utilized semi-structured questioning, which meant that all interviewees were asked identical questions, but additional questions were also used to elaborate, probe and expand on particular topics where necessary. This flexibility ensured that important and salient topics were not excluded from the interview, and also provided enough structure to ensure comparability of responses. The interview questions relevant to this paper were:

1. How would you describe the job of a secondary classroom music teacher to someone who is completely unfamiliar with what music teachers do?

2. What impact has your university teacher education course had on your experiences in your first few years at school?

3. What experiences have you had that you were not well prepared for?

Interviews took place across a wide variety of sites - most commonly at the school of the teacher (if in Metropolitan Brisbane), or by telephone interview (if the interviewee lived outside Metropolitan Brisbane). All interviews were audio recorded and then transcribed with participants’ consent.

Ballantyne, J. (2007) Crossing barriers between teacher preparation and teaching: Documenting praxis shock in early-career4 music teachers. International Journal of Music Education. 25(3), 181-191. Found online at http://ijm.sagepub.com/ 
Interview data were subjected to content analysis to identify themes, concepts and meanings emerging from participants' discussions in interviews (Burns, 2000). Analysis in the current study involved:

- Reading transcripts and noting and coding themes as they emerged. Themes were continually compared with one another to ensure internal homogeneity and external heterogeneity (themes held together meaningfully, and differences between the themes were clear) (Cavana, Delahaye, \& Sekaran, 2001). Adjustments were made as necessary throughout the process of content analysis.

- Examining transcripts to see how categories interrelated and clustered together. Sub themes and new themes emerged at this stage.

- Re-examining categories for similar content, and ensuring that excluded content was not relevant. Changes were made to category labels if necessary.

- Examining and mapping relationships across categories in order to create a greater understanding of the research area.

- Frequently revisited themes and raw data were to check, question or support various arguments as the report was written

The content analysis used in this study used coding for manifest content (Wallen \& Fraenkel, 2001). Manifest content is that which is directly said in the interviews, whereas latent content is that which is implied. Pseudonyms were used in the reporting of data and the quotes presented are representative of the majority of interviewees’ responses, unless otherwise stated.

\section{Results and discussion}

Participants' responses to the interview questions revealed that praxis shock was a common experience for early-career teachers in this study. Their responses provide insight into the factors underlying praxis shock and steps that might be taken to address it.

\section{The experience of praxis shock}

When asked to comment on the impact of their pre-service programs, most early-career music teachers indicated that they felt ill-prepared for the realities of teaching, reporting that "I just 
learnt on the job” (Claire), “I was not well prepared” (Susan, Joy, Grant, Carolyn, Jessica, Roy, Fiona, Claire) and "I honestly had no idea what's going on” (Lotte). Participants used these phrases, together with more direct statements such as “it was a shock” (Roy, Jessica), to refer to praxis shock in different areas of their early experiences. Although praxis shock is well documented among teachers of all discipline areas, music teachers tend to link the 'shock' that they experienced to the specific nature of music teaching.

Well because we weren't prepared for any of that at university, it was a shock when I got out, and I was working much harder than I thought that I would have to. And in my first couple of weeks as a teacher I went up to the principal and I said: "this is ridiculous! I'm doing as many classes as everybody else, and I'm taking the choir and the band and all of that, and I'm a first year teacher, and it is just ridiculous," because it was such a shock to me that all of this stuff fell to you, and it didn't fall to anyone else.

As previously indicated, praxis shock occurs where there are discrepancies between teachers' expectations of school life and the realities of teaching. It is important therefore to determine where these perceived discrepancies exist in order to understand the factors underlying the experience of praxis shock.

Factors underlying praxis shock

To better understand the context of early-career music teachers, interviewees were asked to describe the job of a secondary classroom music teacher as if to someone who was completely unfamiliar with classroom music teaching in Queensland. Analysis of the participants' responses identified two factors underlying the experience of praxis shock:

- $\quad$ physical and professional isolation within the school; and

Ballantyne, J. (2007) Crossing barriers between teacher preparation and teaching: Documenting praxis shock in early-career6 music teachers. International Journal of Music Education. 25(3), 181-191. Found online at http://ijm.sagepub.com/ 
- high workload and multiple responsibilities associated with the extra-curricular music program.

As a result of these factors, early-career music teachers in the current study saw their early experiences in schools as a time where they were left to 'sink or swim', and where they saw themselves as a 'one-man-band'. ${ }^{\text {iii }}$ These perceptions are explored in the following section, along with a discussion of implications for pre-service teacher education.

\section{'Sink or swim': the problem of professional isolation}

A number of participants felt that they had been left to 'sink or swim' in their early years of teaching. In other words, they had been left to fend for themselves with little support from other music teachers or mentors in their own profession. This occurrence was particularly noticeable with early-career music teachers, due to the nature of the subject area. Most schools have few music classes and employ limited numbers of music teachers. As a result, many early-career music teachers felt that despite their pre-service preparation, they were thrown into an unfamiliar environment, where they had to figure out on their own how to survive.

Antoinette I certainly was thrown into the deep end and had to learn to swim ... So that was hard - coming in as the only music teacher, and to coordinate as well. I was thrown in in the deep end.

Comments such as these are consistent with the findings of Rolley (2001) who argues that early-career teachers are frequently being told to 'forget all you've learnt at uni', which results in teachers relying on "inner resources rather than systemic, supportive structures" to survive (Rolley, 2001, p. 40). Perceived isolation was viewed as contributing towards the praxis shock experienced by the early-career music teachers in this study. This is consistent with findings reported by McCormack and Thomas that "beginning teachers who perceived 
themselves as isolated, either through location or lack of support from school personnel ... appeared more concerned about 'survival' issues” (2003, p. 135).

The physical isolation of music teachers in schools (the music department is often physically separated due to the amount of 'noise' created) as well as from other music teachers (many music departments consist of only one music teacher) exacerbates the difficulties faced by early-career music teachers. Isolation often results in teachers feeling 'traumatised', which affects their professional development and has also been linked to music teacher dropout (Kelly, 1999; Krueger, 1999; Krueger, 2000). These research findings were supported by the current study. An example of this is seen in Jessica's comments about expecting less isolation and more professional support in her first few years at school:

Jessica I was the only music teacher, my head of department has no idea about music, got sick during my first year and wasn't here, so I just had nobody, nothing ... I think it was sort of flying by the seat of my pants, getting into the classroom and keeping the kids organised, but I don't think I was giving the kids any quality knowledge, or understanding, and that same first year we did the musical, which made it even worse ... I couldn't even remember where I was meant to be, let alone trying to teach the kids something exciting and wonderful, it just didn't happen.

The experience of professional isolation probably occurs among early-career teachers of all disciplines and has also been documented in the UK among music teachers in general (Spruce, 2002). However, from the analysis of these interviews, it seems that early-career music teachers may be experiencing this isolation in a more acute way, due to the unique demands of teaching music, and the fact that they do not feel adequately prepared for this by 
their pre-service education. This experience of professional isolation appears to be a major factor leading to praxis shock.

The 'one man band': the problem of high workloads and multiple responsibilities

Many of the early-career teachers in this study felt that they had high workloads and were expected to perform multiple roles, beyond that of other classroom teachers. For example, they not only taught their share of classes, but also were expected to coordinate and promote the extra-curricular music program. The perception of a music teacher being a 'one-manband' was suggested by one of the early-career teachers (Carolyn) and was supported by the comments of most respondents. It is a useful way to view early-career music teachers' perceptions of their profession and the multiple responsibilities that music teachers have within the classroom, as coordinator of the extra-curricular program, and in promoting the music programs and the school. Such multiple responsibilities tend to fall to early-career music teachers because they are often the only music teacher in the school.

Interviewees associated the notion of a 'one-man-band' with the incidence of 'burnout'. iv They mentioned that it is considered 'normal' for a music teacher to 'burnout' after about 4-5 years if they have been doing their job 'properly' or 'well'. 'Burnout' was perceived to be specific to the distinctive nature of their job, particularly if teachers tried to accomplish everything that was expected of them to a high standard. Carolyn candidly explains how being a 'one man band' resulted in her feeling 'burnt-out'.

Carolyn To be good at your job, especially as a music teacher ... you have to work your absolute butt off ... you're a one-man-band often as a music teacher ... to be the one-man-band is hard work, you don't get breaks, you don't get spares. They don't exist. And so ... I was burnt out, and I still am ... music music teachers. International Journal of Music Education. 25(3), 181-191. Found online at http://ijm.sagepub.com/ 
teaching specifically is like that ... burnout, I think, it happens to everyone who is doing their job well.

The idea that workload expectations are higher for music teachers than for teachers of other subject areas came through strongly in the interviews, in particular "because the expectations are very high and the workload is very high too" (Grant). This high workload stems from the expectations (from school administration and the community) that classroom music teachers will be involved in all musical activities at the school, not only in the classroom, regardless of whether they have developed skills in those areas:

Janis I guess ultimately you're expected to be a 'jack of all trades' when you become a music teacher, you're the person who's got to work the sound, who's got to work amplifiers and things like that. And if you're not trained in that area, like I wasn't, I've just sort of learned it as I've gone along. I would have had a lot more confidence going into teaching if I had that experience already.

All of the interview respondents reported being heavily involved with the instrumental and extra-curricular music program. ${ }^{\mathrm{v}}$ Research has shown that the extra-curricular music program is more valued by the school than the classroom music program (Lierse, 1999), yet an earlier study indicated that this area was perceived by early-career teachers to be the one area in which they were least well prepared (Ballantyne \& Packer, 2004). Interview responses confirmed that early-career music teachers considered their involvement in extracurricular programs to underly their experience of praxis shock.

Fiona Everything that is required is done outside classroom time. A lot of it is not timetabled into class and is expected for us to do it, however, we are not

Ballantyne, J. (2007) Crossing barriers between teacher preparation and teaching: Documenting praxis shock in early-care£10 music teachers. International Journal of Music Education. 25(3), 181-191. Found online at http://ijm.sagepub.com/ 
paid extra for it and it is a core element of our teaching program, so it is done at lunchtime, before school, after school, weekends, night time concerts ... it's huge.

Although the concern about not 'being paid' for this extra work was raised by many teachers, it was unclear whether increased pay would assuage this problem. Most teachers interviewed accepted their role in the extra-curricular program and saw it as part of the job. However, they felt unprepared for the time that the extra-curricular program demands.

Carolyn: $\quad$ Nobody tells you how much time it takes for you to do all these things ... They don't prepare you for that as a music teacher specifically.

Although most early-career music teachers reported having extra-curricular music activities "thrust upon them” (Roy), one interviewee (Grant) noted that the extra-curricular program complemented his classroom program very well. Preparation for this responsibility, as well as the provision of adequate support for music teachers in the school was viewed as crucial if these expectations are to be met.

The concept of a 'one-man-band' was perceived to be a unique problem associated with the high workloads and multiple responsibilities placed upon early-career music teachers. Their role as coordinator of various extra-curricular programs and activities in their own time is seen as being integral to the job (yet not usually part of their teaching load). In addition, the school and community see this involvement as being the most important role of the music teacher and the need to perform in concerts in front of peers creates additional pressure. Teachers reported that they did not feel prepared for this following their pre-service teacher education, resulting in feelings of 'shock'.

Ballantyne, J. (2007) Crossing barriers between teacher preparation and teaching: Documenting praxis shock in early-careqr1 music teachers. International Journal of Music Education. 25(3), 181-191. Found online at http://ijm.sagepub.com/ 


\section{Implications for teacher education}

This paper has explored the reported experiences of early-career Australian music teachers in the secondary schools, and their perceived preparedness to deal with these experiences. These teachers described feelings of physical and professional isolation and difficulties dealing with the high workload and multiple responsibilities outside the music classroom. Expectations regarding their involvement in the extra-curricular music program seemed to cause particular problems for early-career music teachers. The areas where they felt most unprepared were perceived to be specific to their role as music teacher. When describing early experiences in teaching, interviewees continually repeated that the problems experienced were a 'shock' to them following their pre-service preparation. In short, they did not feel that their pre-service education had prepared them adequately for these aspects of being a secondary classroom music teacher.

It should be noted that teachers interviewed in this study were not entirely negative about their pre-service preparation, or their experiences in the classroom. On the contrary, they reported a 'passion' for teaching music (Ballantyne, 2005), and felt that praxis shock could be addressed in both the university and school settings.

Within the university setting, interviewees spoke of the need for pre-service teacher education courses to prepare future teachers for the realities of the working environment (in this case as secondary classroom music teachers). Indeed, Stokking, Leenders, De Jong, and Van Tartwijk (2003) argue that "a thorough and realistic preparation of candidate teachers may reduce ... the intensity of the practice shock and the resulting dropout of prospective and novice teachers” (p. 331). Teacher education courses that are contextualised, integrated and continue to support teachers after they have graduated will be best situated to reduce praxisshock in early-career music teachers (Ballantyne, in press). It is therefore maintained that:

- An examination of the 'realities' of teaching will better equip pre-service teachers for their future contexts. By ensuring that pre-service teachers experience 'real' teaching

Ballantyne, J. (2007) Crossing barriers between teacher preparation and teaching: Documenting praxis shock in early-careqr2 music teachers. International Journal of Music Education. 25(3), 181-191. Found online at http://ijm.sagepub.com/ 
situations throughout their studies (through, for example, integrated practicum opportunities, problem-based learning opportunities and interaction with a variety of music teachers in many different contexts), students will be able to critically reflect on and prepare for their future context.

- Teacher education should integrate music, education and professional knowledge and skills across all areas of the course. Integrated teacher education involves assisting pre-service teachers to see the links that exist between their general education and music courses and between theory and practice. This requires extensive planning within courses, across courses and between schools, the community, and universities. It is suggested that effective integration modelled in teacher education would translate to the adoption of effective integration practices by future teachers.

- Although the incidence of praxis shock may be minimised by a pre-service course that prepares students for their future context (in a constructivist and reflective way), this should just be the beginning of the ongoing education of early-career teachers. Inservice teacher education should also address issues associated with praxis shock. By addressing the unique problems that these secondary school music teachers face (as argued above) and their need for discipline-specific induction and mentoring programs (as suggested by Conway, 2001; DeLorenzo, 1992; Krueger, 1999, 2000, 2001; Yourn, 2000), in-service teacher education might better be able to assist earlycareer music teachers as they are experiencing difficulties.

This study has highlighted the need for further research into in-service music teacher education as well as the working conditions of music teachers. It would also be useful to explore the experiences of early-career primary music teachers, as it is not certain how their experiences in the first few years of teaching might be different to secondary teachers' experiences. A study of itinerant music teachers (Roulston, 1998) indicated similarities to the present study, where teachers reported difficulties with heavy workloads and a sense of belonging. Although Roulston's study did not focus on early-career teachers, it is possible that the itinerancy of primary school music teachers might exacerbate the praxis shock of Ballantyne, J. (2007) Crossing barriers between teacher preparation and teaching: Documenting praxis shock in early-careqr3 music teachers. International Journal of Music Education. 25(3), 181-191. Found online at http://ijm.sagepub.com/ 
these teachers as they begin their careers. This has not been established by the current study, and is an area for future research.

This paper has documented the praxis shock evident in early-career secondary school music teachers in Australia. Although directly relevant to music teacher education, the findings of this study may also be of interest to other areas of teacher education where early-career teachers may experience physical and professional isolation, high workload, and multiple responsibilities over and above their classroom commitments. It is suggested that pre-service and in-service teacher education programs be designed to minimise the incidence of praxis shock, particularly through providing contextualisation, ongoing professional development and mentoring. Such programs are most likely to meet the needs of early-career teachers.

\section{Acknowledgements}

This article is based on the authors Doctoral dissertation awarded in 2005 by the Queensland University of Technology. My sincere thanks go to Dr Jan Packer, for her thoughtful and insightful comments on my work. Thanks also the participants of this study, for their time in speaking to me. Thank you to the participants of the 2006 MISTEC conference who listened to my paper on this topic, and provided valuable comments.

\section{References}

Ballantyne, J. (2008). Integration, Contextualisation and Continuity: Three themes for the development of effective music teacher education programs. International Journal of Music Education.

Ballantyne, J. (2006). Reconceptualising preservice teacher education courses for music teachers: The importance of pedagogical content knowledge and skills and professional knowledge and skills. Research Studies in Music Education, 26, 37-50.

Ballantyne, J. (2005). Identities of music teachers: Implications for teacher education. Paper presented at the Australian Teacher Education Association Conference, Gold Coast, July 2005.

Ballantyne, J., \& Packer, J. (2004). Effectiveness of pre-service music teacher education programs: Perceptions of early-career music teachers. Music Education Research, 6(3), 299-312.

Burns, R. (2000). Introduction to research methods (4th ed.). Sydney: Pearson Education Australia.

Ballantyne, J. (2007) Crossing barriers between teacher preparation and teaching: Documenting praxis shock in early-careqr4 music teachers. International Journal of Music Education. 25(3), 181-191. Found online at http://ijm.sagepub.com/ 
Cavana, R. Y., Delahaye, B. L., \& Sekaran, U. (2001). Applied business research: Qualitative and quantitative methods. Brisbane: John Wiley and Sons.

Conway, C. (2001). What has research told us about the beginning music teacher? Journal of Music Teacher Education, 10(2), 14-22.

Conway, C. (2002). Perceptions of beginning teachers, their mentors, and administrators regarding pre-service music teacher preparation. Journal of Research in Music Education, 50(1), 20-36.

DeLorenzo, L. C. (1992). The perceived problems of beginning music teachers. Bulletin of the Council for Research in Music Education, 113, 9-25.

Flores, M. A. (2001). Person and context in becoming a new teacher. Journal of Education for Teaching, 27(2), 135-148.

Ghaith, G., \& Shaaban, K. (1999). The relationship between perceptions of teaching concerns, teacher efficacy, and selected teacher characteristics. Teaching and Teacher Education, 15, 487-496.

Gratch, A. (2001). The culture of teaching and beginning teacher development. Teacher Education Quarterly, 28(4), 121-136.

Hawkey, K. (1996). Image and the pressure to conform in learning to teach. Teaching and Teacher Education, 12(1), 99-108.

Kelchtermans, G., \& Ballet, K. (2002). The micropolitics of teacher induction. A narrativebiographical study on teacher socialisation. Teaching and Teacher Education, 18, 105-120.

Kelly, J. (1999). What stress factors specific to music teaching are critical to 'burnout' in secondary school classroom music teachers in Queensland? Paper presented at the ASME XII National Conference, University of Sydney, N.S.W.

Krueger, P. J. (1999). New music teachers speak out on mentoring. Journal of Music Teacher Education, 8(2), 7-14.

Krueger, P. J. (2000). Beginning music teachers: Will they leave the profession? Update: Applications of research in Music Education, 19(1), 22.

Krueger, P. J. (2001). Reflections of beginning music teachers. Music Educators Journal, 88(3), 51.

Lampert, M., \& Ball, D. L. (1999). Aligning teacher education with K-12 reform visions. In L. Darling-Hammond \& G. Sykes (Eds.), Teaching as the learning profession: Handbook of policy and practice (pp. 33-53). San Francisco: Jossey-Bass Inc.

Leong, S. (1996). The relationship between music competencies perceived as important for novice teachers and the professional expectations of high school music teachers in Australia. Unpublished PhD, University of Western Australia, Perth.

Lierse, A. (1999). Under threat again. In M. S. Barrett, G. E. McPherson \& R. Smith (Eds.), Children and music: Developmental perspectives. Proceedings of the 2nd AsiaPacific Symposium on Music Education Research and the XXI annual conference of the Australian Association for Research in Music Education (pp. 168-173). Launceston, Tasmania: International Society for Music Education.

Mark, D. (1998). The music teacher's dilemma - musician or teacher? International Journal of Music Education, 32, 3-23.

Martinez, K. (1994). Postcards from the edge. In Knowledge and competence for beginning teaching. Brisbane, Queensland: Board of Teacher Registration, Queensland.

McCormack, A., \& Thomas, K. (2003). Is survival enough? Induction experiences of beginning teachers within a New South Wales context. Asia-Pacific Journal of Teacher Education, 31(2), 125-138.

Ballantyne, J. (2007) Crossing barriers between teacher preparation and teaching: Documenting praxis shock in early-care 15 music teachers. International Journal of Music Education. 25(3), 181-191. Found online at http://ijm.sagepub.com/ 
Queensland Board of Teacher Registration. (1999). Guidelines on the acceptability of teacher education programs for teacher registration purposes. Brisbane: Queensland Board of Teacher Registration.

Ramsey, G. (2000). Quality matters. New South Wales: Department of Education and Training.

Richards, C., \& Killen, R. (1993). Problems of beginning teachers: Perceptions of pre-service music teachers. Research Studies in Music Education, 1(1), 40-51.

Rolley, L. (2001). Another cry in the wilderness? Unicorn, 27(3), 37-41.

Roulston, K. (1998). Music teachers talk about itinerancy. Queensland Journal of Educational Research, 14(1), 59-74.

Scheib, J. (2003). Role stress in the professional life of the school music teacher: A collective case study. Journal of Research in Music Education, 51(2), 124-136.

Shulman, L. S., \& Sparks, D. (1992). Merging content knowledge and pedagogy: An interview with Lee Shulman. Journal of Staff Development, 13(1), 14-16.

Spruce, G. (2002). The music department. In G. Spruce (Ed.), Aspects of teaching secondary music. London: RoutledgeFalmer.

Stokking, K., Leenders, F., De Jong, J., \& Van Tartwijk, J. (2003). From student to teacher: Reducing practice shock and early dropout in the teaching profession. European Journal of Teacher Education, 25(3), 329-350.

Stuart, C., \& Thurlow, D. (2000). Making it their own: Pre-service teachers' experiences, beliefs, and classroom practices. Journal of Teacher Education, 51(2), 113-121.

$\mathrm{Su}$, J. Z. X. (1992). Sources of influence in pre-service teacher socialisation. Journal of Education for Teaching, 18(3), 239-259.

Temmerman, N. (1997). An investigation of undergraduate music education curriculum content in primary teacher education programmes in Australia. International Journal of Music Education, 30, 26-34.

Wallen, N., \& Fraenkel, J. (2001). Educational research: A guide to the process. In (2nd ed.). Mahwah, New Jersey: Lawrence Erlbaum Associates.

Wheatley, K. F. (2002). The potential benefits of teacher efficacy doubts for educational reform. Teaching and Teacher Education, 18, 5-22.

Wideen, M., Mayer-Smith, J., \& Moon, B. (1998). A critical analysis of the research on learning to teach: Making the case for an ecological perspective on inquiry. Review of Educational Research, 68(2), 130-178.

Yourn, B. R. (2000). Learning to teach: Perspectives from beginning music teachers. Music Education Research, 2(2), 181-192.

\footnotetext{
${ }^{\mathrm{i}}$ An earlier version of this paper was presented at the International Society of Music Education, Music in Schools and Teacher Education Commission in Hong Kong, July 2006.

Ballantyne, J. (2007) Crossing barriers between teacher preparation and teaching: Documenting praxis shock in early-care 16 music teachers. International Journal of Music Education. 25(3), 181-191. Found online at http://ijm.sagepub.com/
} 
ii For the purposes of this study, the term 'early-career teacher' refers to teachers in their first four years teaching.

iii The separation of these categories is helpful in the analysis of the data. It must, however, be stressed that these two categories are interconnected in many ways.

iv 'Burnout' was also associated, to a lesser extent, with the notion of 'sink or swim'.

${ }^{v}$ A third (32\%) of all respondents to the questionnaire were employed as instrumental teachers (as well as classroom teachers).

Ballantyne, J. (2007) Crossing barriers between teacher preparation and teaching: Documenting praxis shock in early-careqr7 music teachers. International Journal of Music Education. 25(3), 181-191. Found online at http://ijm.sagepub.com/ 